\title{
The social perception of urban transport in the city of Madrid: the application of the Servicescape Model to the bus and underground services
}

\author{
María Luisa Delgado Jalón, Alba Gómez Ortega* [D and Javier De Esteban Curiel
}

\begin{abstract}
Purpose: This paper is a study of the user's perception of urban and suburban transport and was carried out in an attempt to compare the social value of various means of transport. The measurement of social perceptions is carried out with regard to ambient conditions, space, signs, front-line employees and other customers as stakeholders of both public transport services. Thus, this paper aims to identify the reasons for individuals' preferences when choosing one particular means of transport for their daily life.

Results: The results show that user perceptions of the underground are slightly better than the perceptions of buses; the results also highlight the decent management of both means of transport in terms of quality air, temperature, space, noise, cleanliness, smell and seating facilities. Some modest improvements are recommended to enhance public transportation service delivery.

Conclusions: This approach reflects the gap between the social perception of a service and companies' financial situations. Management policies are necessary to improve the service's social value.
\end{abstract}

Keywords: Users' perception, Mobility, Public transport, Servicescape model

\section{Introduction}

No one doubts the need for a collective transport system in cities. In any economy, regardless of its level of development, people must move around during their daily routine for both work and leisure purposes. When cities grow, the combined relationships between urban nuclei and metropolitan areas make this movement more difficult. Neirotti et al [51] state that cities currently must be identified as complex systems, with large populations, businesses, services and interconnected transport means. Mobility necessities may lead to problems in terms not only of congestion but also pollution, noise and economic cost $[2,7,44]$. These problems are worse in the urban sphere, in which the majority of the population is concentrated [35].

\footnotetext{
* Correspondence: alba.gomez@urjc.es

Business Economic Department, King Juan Carlos University, Paseo de los Artilleros, s/n, 28032 Madrid, Spain
}

According to Diab and El-Geneidy [27], many transit agencies implement a number of strategies to provide an attractive transportation service.

Numerous studies have analysed business efficiency in the sector. Thus, there are studies from the perspective of costs and revenues [17, 24]; other studies analyse the efficiency of frontier models, i.e., the AEDs and the like [8, 40,41 ]. On the other hand Sampaio, et al., [58] and [39] provide an interesting literature review of studies related to the analysis of efficiency in transport until 2011. However, few researchers have combined this work with the social value of the service provided or the users' perception of that value $[13,36,54,67]$. The effectiveness of each applied transport policy depends significantly on the level of agreement among stakeholders, making collaboration a prerequisite for success [57]. This motivated our interest in carrying out our own study, which is focused on analysing the value perceived by final users. 
Our objective is to obtain a profile of the demand for transport service and compare the value of public transport in its various forms as bus and underground services as perceived by the user. In this way, the operating entities can use the competitive advantage that knowing user preferences represents and thus increase its appeal.

\subsection{The perception of social value in collective urban transport}

From the social point of view, transport has a tremendous influence on social relationships in increasing individuals' social and cultural possibilities. It has made it possible to separate the distance between the workplace and the home to a much greater extent than ever before, thus enabling a more comfortable lifestyle [64]. Boniface et al. [13], review the evidence that transport impacts social interactions and that social interactions impact health. Utsunomiya [67] has attempted to determine the role of local public transportation beyond social benefits.

Transforming cities and understanding the role of public transport services from the perspective of cities in an international context by embedding social and environmental perspectives is becoming highly challenging [54].

In short, many papers analyse the social value of transport and its effects: waiting times [65], pollution reduction, environmental impact [13, 21], social integration and interconnection [23, 47, 67]. However, there are few and more recent studies that attempt to analyse the social value from the users' perception and feelings.

Social value from a user's perspective has been analysed mainly by studies focused on service quality. Hence, Dell'Olio et al. [26] carry out a quality analysis based on the services desired by users and potential users of public transport. In addition, Abenoza et al. [1], through a cluster analysis, re-identify commuting time as one of the main determinants of satisfaction in the Swedish public transport service. Other studies related to quality and user perception are [25], [28], [55], [43], [50], and [36], among others.

Hernández et al. [36] consider that in order to define an efficient transport interchange it is necessary to identify the key factors from both a functional and a psychological perspective, since the users' perceptions of their experience are particularly important as regards achieving the most appropriate policy measures for interchanges. Gatersleben et al. [31] explore the idea that such judgements are affected by the means of transport they use. Iseki and Taylor [38] analyse ways of reducing the perceived burdens of out-ofvehicle time spent walking, waiting, and transferring to improve users' experience at transit stops and stations.

All of the above led us to the conclusion that it is necessary to use new perspectives to manage transport, perspectives focused on more demanding user-oriented approaches in order to discover the degree to which customers/users' perceptions and expectations of quality influence their decisions when travelling.

We have carried out the study from the perspective of social perception, applied specifically to the city of Madrid and using the Bitner Model, with the Servicescape Model, as a basis. This has allowed us to obtain the social perceptions of a determined service. This model was chosen for various reasons: first, it is a relatively recent and innovative model and is continuously being put into practice in various sectors and research fields; second, although it has been applied to numerous types of services, it has not, to date, been applied to our study object: urban transport as a public service. Lastly, it is an appropriate means of analysing the social perception of transport service, thus enabling us to uncover the motives behind users' preferences for either buses or the underground service.

\subsection{The Servicescape model}

The core of the Servicescape Model is that it considers elements that conform to the environment in which the service is produced in order to understand consumers' behaviour and observe how it influences certain changes in their purchase decisions. By 'environment' we mean both the physical space in which the service is produced and the interaction among employees, the consumer and other consumers.

The influence of the physical environment on consumers has been recognised in marketing, fundamentally in retail sales and in organisational contexts. In the last decades of the twentieth century, numerous psychologists explored the impact of the physical space and its influence on consumer behaviour $[9,42,60,66]$. In 1973, Kotler was one of the first to suggest that the place in which a product is consumed influences consumers' purchase decisions. He introduced the term 'atmosphere' to describe "the conscious designing of a space to create certain effects on buyers".

Gardner [30], states that small changes in the physical environment may influence consumers and their state of mind when making a purchase. Spies et al. [62] detected that the atmosphere does not affect the total amount of money spent, but only the amount spent on impulse buys. According to these authors, customers spend more money on impulse buys in more pleasant environments.

In 1992, Bitner published the Servicescape conceptual framework (Fig. 1), into which she integrated empirical findings and compiled theories along with a theory that she had developed herself, and this became one of the most widely recognised concepts in the research in this field. Bitner justifies her work with the idea that the physical environment is of great importance to service companies since the product is "produced and consumed simultaneously". Behaviour such as interaction in small groups, the forming of friendships, participation, 


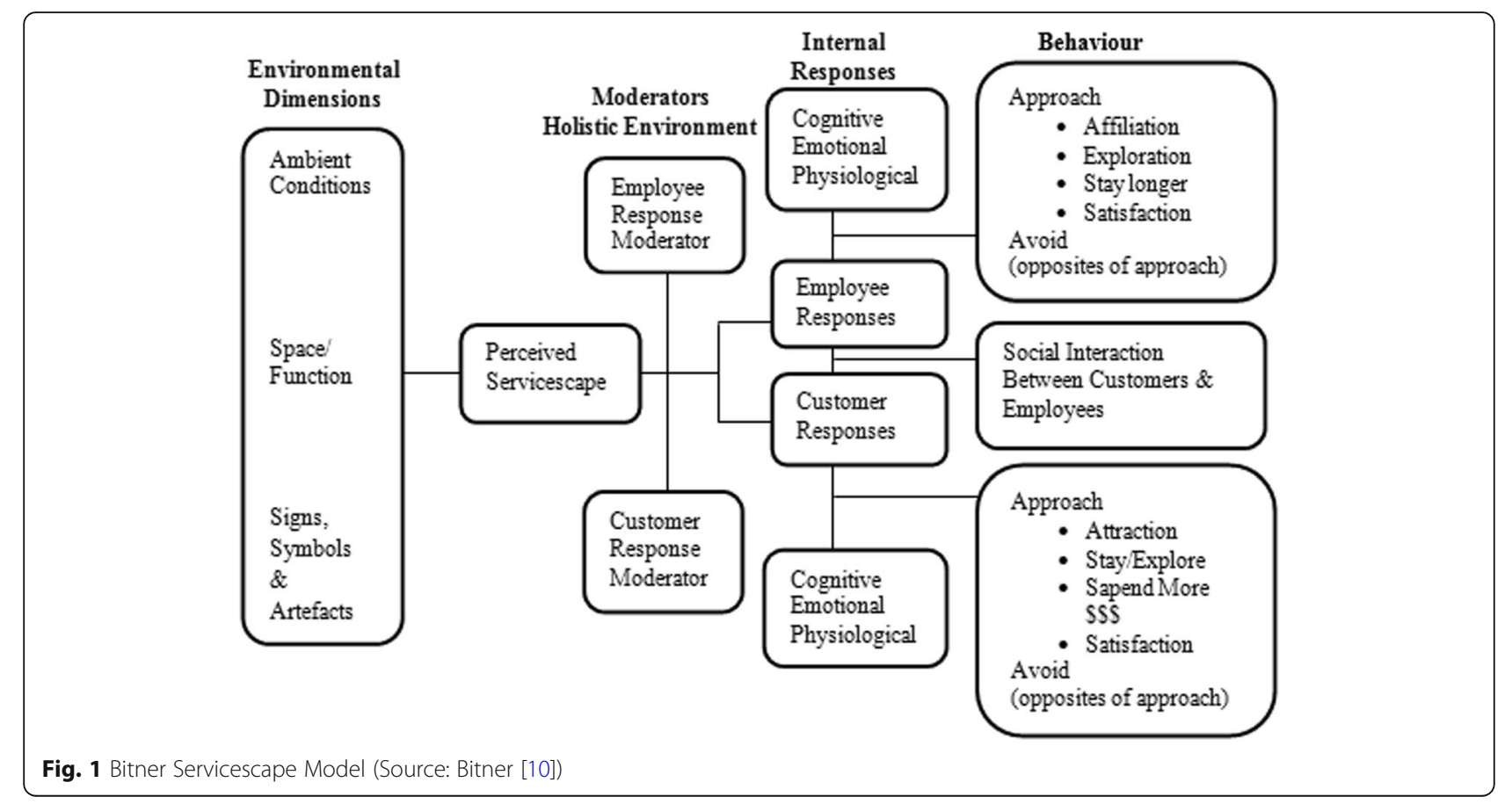

aggression, withdrawal and the wish to help others have proved to be influenced by environmental conditions [37].

In addition, the people who participate in that environment may give form to and influence the physical space itself and its impact. This 'social atmosphere' is included in a wider definition of Servicescape, in which the influence of other consumers on the consumer in question's perception of the service is also taken into consideration [5, 6]. According to Šimeček et al. [61], a model that would reflect reality more reliably would include relevant psychological factors (such as perceptions or attitudes) or generally human elements influencing theirs choices. Although it would be possible to broaden the concept of Servicescape to include the natural, cultural, temporal or political environments, these definitions of the environment are not within the scope of the present effort [63].

\subsection{Practical application of the model}

It is now necessary to examine the works that show the practical application of the model and provide a solid basis for its application in this research. According to Reimer and Kuehn [56], although previous studies have revealed the importance of Servicescape, its effect on the quality perceived in the service had not been adequately analysed. Pantouvakis [53] attempted to evaluate the relative importance of the various dimensions of service quality by proposing a new Servicescape model that would place more importance on the physical attributes of the environment than in previous studies.
Lin and Worthley [45] examined various Servicescapes as a moderated variable in an integral model of the individual features of personality, emotions, satisfaction and approximation-rejection behaviours. Orth et al. [52], meanwhile, explored the interior design of commercial services and environments and tested a conceptual model related the types of interior designs, including the consumers' impressions and the personality of that environment.

The study by Choo and Petrick [20] on social interactions and the intention to repeat the experience of agrotourism approached how interactions influence satisfaction. These authors believe that it is necessary to focus on encounters in which the customer interacts with the personnel and/or other customers [12]. According to the marketing literature, employees' interpersonal skills affect customer satisfaction and their behaviour [11, 14], and customers influence each other either indirectly as a part of the environment or directly through interpersonal encounters. Brunner et al. [15] carried out a study in the tourism sector and found that the consumer attempted not only to find professionalism in the provision of the service but also to attain satisfaction as regards emotional experiences, and they considered that it is important to know the antecedents and consequences of customer satisfaction.

Having carried out the above literature review, we thought it would be useful to use this model in our study, since it would appear to be an appropriate means of analysing the user's final social perception of bus 
service when compared to underground service. We have applied the model by creating a questionnaire that attempts to consider all the contributions developed by the various authors mentioned previously over the last few years.

\section{Methods}

\subsection{Definition of hypothesis}

There is substantial literature providing evidence that people tend to prefer rail transit to bus transit $([4,16,59]$; among others), even when service characteristics are similar. With that as a starting point, it would be valuable to determine which elements of the public transportation "atmosphere" are most valuable for public transportation users. This could help transit companies better tailor their marketing campaigns, as the paper suggests.

Thus, the hypothesis that we attempt to validate in this work is as follows:

Ho: The underground service is better valued socially than the bus service.

The analysis of the survey results will allow us not only to validate this hypothesis but also to shed light on some of the motives for these preferences, and on the importance and value that users give to different aspects of the service received.

\subsection{Information-gathering technique: the face-to-face survey}

The information-gathering technique employed was a questionnaire. We decided upon a face-to face survey. According to Creswell [22], a face-to-face survey design is a procedure in quantitative research in which the researcher surveys a sample of people in order to describe the population's attitudes, behaviour, opinions or characteristics. Precise samples are selected for this kind of surveying and attempts are made to standardise and eliminate errors from data-gathering tools [32]. Moreover, Hair et al. [34] state that a face-to-face survey design has several advantages, among them that the interviewer can explain confusing and complex questions using visual aids.

The questionnaire used for this survey was filtered beforehand by means of a pilot pre-test. This pre-test consisted in trying the questionnaire on a small sample of the objective public fairly divided among administrative personnel, academic research staff and university students. Next, a complete double validation was performed comprising a) qualitative analysis (surveyed individuals' perceptions) and quantitative (Chronbach's Alpha test) analysis of the obtained results, and b) expert validators' review, which approved the final content of the questionnaire.

The final questionnaire consisted of a formalised set of questions (Table 1) regarding each of the blocks in Servicescape.

The types of questions used were, on the whole, closed. Both dichotomous and multiple-choice questions were used. In the first part, the socio-demographic profile, the questions concerned classification in order to segment the population and discover any possible influence on the responses. A Likert scale was used in most of the questionnaire, and the responses had values of 1 to 5 according to the sense of the sentence. With regard to the open question, naming other questions, we had to create a code of responses in order to transform it into a closed response question (Table 2).

The sample size has been determined by the optimal point between the size and the sampling error that might work out. We applied the following sampling error formula:

$$
\mathrm{K}=2 \sqrt{ }[(\mathrm{p}(1-\mathrm{p}) / \mathrm{n}]
$$

(Source: [29])

Assuming the sample size "n" is 250 for bus and 250 for underground. For "p", we assume maximum dispersion, i.e., all elements in the questions have the same probability of being chosen:

$$
\mathrm{p}=\mathrm{q}=0,5
$$

Working out the formula, " $k$ " for the bus and underground survey is $6.4 \%$. In sum, the results obtained in our sample fluctuate from $+/-6.4 \%$ at a $95 \%$ confidence level in the total population.

The non-response rate was approximately $2 \%$ and the negativity rate was between $10 \%$ and $20 \%$. The definitive version obtained a Cronbach's Alpha [0.717-0.998], signifying that the questionnaire is highly acceptable (see Table 2). The Cronbach's Alpha obtained for the socio-demographic profile was low, although it is logical that there is a high dispersion of responses in this type of data, and it is even

Table 1 Design of the questionnaire applied in this research paper

\begin{tabular}{lll}
\hline Block & Interval of Bus questions & Interval of Underground questions \\
\hline 1. First Impressions & $1-15$ & $1-16$ \\
2. 'Feeling' or Internal Responses & $16-25$ & $17-25$ \\
3. Behaviour & $26-39$ & $26-39$
\end{tabular}

(Source: Authors)203. 
Table $\mathbf{2}$ Cronbach's Alpha of the questionnaires used for this research

\begin{tabular}{|c|c|c|c|c|c|c|}
\hline \multirow{2}{*}{$\frac{\text { Alpha obtained }}{\text { Block of questions }^{a}}$} & \multicolumn{3}{|l|}{ Bus } & \multicolumn{3}{|c|}{ Underground } \\
\hline & $\begin{array}{l}\text { Cron- } \\
\text { bach's } \\
\text { Alpha }\end{array}$ & $\begin{array}{l}\text { Cronbach's } \\
\text { Alpha } \\
\text { based on } \\
\text { the } \\
\text { elements } \\
\text { typified }\end{array}$ & $\begin{array}{l}\mathrm{N}^{\circ} \text { of } \\
\text { ele- } \\
\text { ments }\end{array}$ & $\begin{array}{l}\text { Cron- } \\
\text { bach's } \\
\text { Alpha }\end{array}$ & $\begin{array}{l}\text { Cronbach's } \\
\text { Alpha } \\
\text { based on } \\
\text { the } \\
\text { elements } \\
\text { typified }\end{array}$ & $\begin{array}{l}N^{0} \text { of } \\
\text { ele- } \\
\text { ments }\end{array}$ \\
\hline Socio-demographic Profile & .074 & .088 & 10 & .501 & .640 & 10 \\
\hline Very Bad (1) to Very Good (5) & .998 & .998 & 6 & .998 & .998 & 6 \\
\hline Very Bad (5) to Very Good (1) & .746 & .590 & 3 & .727 & .544 & 3 \\
\hline Greatly disagree (1) to Greatly agree (5) & .785 & .685 & 4 & .897 & .858 & 5 \\
\hline Greatly disagree (1) to Greatly agree (5) & .847 & .888 & 9 & .686 & .484 & 8 \\
\hline Very important (1) Not at all important (5) & .984 & .985 & 6 & .977 & .979 & 6 \\
\hline Very few (1) to A lot (5) & .734 & .734 & 3 & .920 & .919 & 3 \\
\hline Very often (1) to Very little (5) & .990 & .990 & 2 & .989 & .989 & 2 \\
\hline Other questions (without Likert scale) & .717 & .597 & 3 & .658 & .522 & 3 \\
\hline
\end{tabular}

(Source: Authors)

${ }^{a}$ The blocks used to calculate the Alpha were defined per type of response

necessary and appropriate because it means that data have been collected for a wide variety of profiles of those surveyed, which makes them more representative. Some authors, such as Hair, Black, Babin, and Anderson [33], consider that obtaining a Cronbach's Alpha of over 0.6 is a good result and that it is perfectly possible to extrapolate the data obtained from the sample to the total population.

\subsection{Technique used to analyse information gathered: statistical analysis}

The first descriptive analysis carried out was divided into two blocks. On the one hand, we carried out a frequency analysis for those questions with non-quantifiable responses that generally corresponded to dichotomous questions and the socio-demographic profile. On the other hand, we carried out a measures and dispersion analysis for those questions with responses measurable on a scale of 1 to 5 .

The bivariant analysis carried out was also divided into two blocks: a) an analysis by means of Contingency Tables and Pearson Chi-Square, and b) an analysis of the correlation among variables by means of the Pearson $\mathrm{Co}^{-}$ efficient of Linear Correlation.

The different categories of the variables that are represented in a contingency table must be exhaustive and mutually exclusive. That is, the set of categories of a categorical variable must be sufficient to classify each and every individual of which the sample population is formed (exhaustivity) [3, 18, 46]. The Pearson Chi-Square coefficient provides the statistical legitimacy needed to allow the results obtained from the contingency tables to be extrapolated from the population sample being studied. As argued by Martín-Pliego and Ruiz-Maya [48], the Chi-Square Test is used as a contrast of independence in the Contingency Tables to verify whether there is a relationship among the variables being studied in those tables.

The bivariant analysis was carried out in the cases of those contingency tables that had a significance associated with a Chi-Square of $<0.05$. Lastly, we studied the correlation among the variables in the questionnaire, two by two, using the Pearson Coefficient of Linear Correlation. This allowed us to identify the degree of linear correlation among the variables. For the model robustness, a linear regression analysis was carried out. This allowed us to calculate the value of these two parameters, thus defining the straight line that best adjusted to the point cloud.

Lastly, all the information regarding the methodology used in this work is summarised in Table 3.

\section{Results and discussion}

We have divided the results into the three blocks of the Servicescape Model: 1) User's first impressions, 2) 'Feeling' or Internal Responses, which are related to the users' more inner sensations, and 3) users' specific 'Behaviour' in response to the perceived service.

\subsection{Block 1: 'first impressions'}

\subsubsection{The characteristics of the environment}

When the user has a positive impression of a physiological aspect of a service, this generally influences the other aspects of the same typology. On a bus, the environment or landscape have a direct influence on the 
Table $\mathbf{3}$ Technical data sheet for the methodology used in this research

\begin{tabular}{ll}
\hline Parameter & Description \\
\hline Type of survey & Self-administered face-to-face \\
Place carried out & City of Madrid \\
Universe or population & Residents in City of Madrid + Visitors \\
Size of sample & 500 (250 at the underground, 250 at the bus) \\
Sample error & $6.4 \%$ \\
Confidence level & $95 \%$ \\
Sample method & Random stratification \\
Date of fieldwork & $17-23$ December 2013, 25 January 2014 \\
Average time per person surveyed & 8 min \\
Negativity rate & Underground: 16\% \\
Non-response rate & Underground: 1.99\% \\
Analysis technique & Statistical analysis: Univariant_Bivariant (correlation) \\
Computer program used for data treatment & Predictive: analysis: Regression Model \\
\hline
\end{tabular}

(Source: Authors)

user's perception. On the underground, however, the characteristics of the external environment do not appear to affect the user's perception, given that its own pre-established subterranean atmosphere has already been created.

One of the most important aspects for the traveller, in terms of the interior design of trains, is the seats. As the user's acquisitive level increases, s/he demands a higher level of quality of noise, cleanliness and smell, comfort, space, temperature and safety. Furthermore, full-time workers are more demanding, as they need their journey to be relaxed and comfortable to alleviate routine stress. Moreover, the older the people surveyed, the more positively they valued the quality of the seats.

\subsubsection{How employees treat users}

The influence of how employees treat users on the perception of the service is not very significant in the case of the underground. With regards to the bus service, however, the response concerning how employees treat users was clearly more positive owing to the interaction with the drivers.

\subsubsection{Symbols, signs and signals}

The signposting at the ends of streets is highly positively valued. Furthermore, the indications of waiting times on screens are a clear priority for the users of both services. As for signposting inside the underground stations, users consider that this allows them to find connections between different lines easily, and this is more important for residents.

\subsubsection{Relationship with other users}

Another relevant factor is the traveller's own interaction with other service users. The most frequent profile corresponds to humble classes. In our opinion, this may discourage certain other members of the public, as they do not wish to be identified with this collective.

\subsection{Block 2: 'feelings'}

Approximately $90 \%$ of those surveyed stated that they knew the Metro de Madrid logotype, while this percentage was $80 \%$ in the case of EMT de Madrid. Thus the policy concerning image and metro brand is much more interiorized in the public than that of EMT.

With regard to the idea that comes to mind when hearing public transport in the city mentioned, this question was raised openly. The details of the respondents' comments comprising the most typical answers are shown in Table 4.

The responses allow us to state that large groups of people very probably imagine themselves on the underground far more than on a bus, and the negative image of the service as a whole may be derived more from the underground service itself. The next ideas associated with the service are divided between 'Communication and Mobility' and those related to 'Economic Aspects'. In the latter case, those surveyed alluded specifically to the cost of the service, which they consider to be expensive, the strikes that take place, too much publicity and cuts to the service.

When deciding which means of transport is considered better, the underground was chosen more frequently (86\%). However, they also stated that both means are complementary and are not exclusive, perceiving the idea of coexistence rather than substituting one means for the other. The underground is fundamentally preferred for its speed, but if it takes second place, because the traveller has more time, is making the trip 
Table 4 The details of the respondents' comments comprising some of the most typical answers

\begin{tabular}{|c|c|}
\hline Typified answers & Detail \\
\hline Bus & The bus is better, the night bus \\
\hline Metro (underground) & "Madrid Metro flies", tunnel \\
\hline Sustainable city & Less pollution, less traffic, less fuel consumption \\
\hline Good quality service & $\begin{array}{l}\text { Very frequent, good connection, speed, comfort, efficiency, useful and practical, usually punctual, effectiveness, } \\
\text { quality, time-saving, arrives early, punctuality, excellence, clean, cheaper travel }\end{array}$ \\
\hline Bad quality service & $\begin{array}{l}\text { Crowded, burglars, chaos, very unpleasant smell, stress, crazy insane, delayed buses, full, useful technology, } \\
\text { noisy, dirty, tardiness, people sweating, very slow, delays, crowded in the mornings, few seats, madness, heat, } \\
\text { dizziness, discomfort, running to get it, stomach upset, agglomerations. }\end{array}$ \\
\hline $\begin{array}{l}\text { The service is worse than it was a } \\
\text { few years ago }\end{array}$ & The wait has worsened, in decline \\
\hline Mobility and Communication & Communication, mobility, proximity, accessibility, good circulation, distances, travel, connections, organisation \\
\hline Economic aspects & Expensive, strikes, has risen a lot, poor value for money, too much publicity, budget cutbacks \\
\hline Comparison with other cities & Good service with respect to other European cities \\
\hline
\end{tabular}

(Source: Authors)

for leisure purposes or is older, then the bus begins to become more popular because the journey is more pleasant and it is possible to enjoy the sights of the city and daylight. One of EMT de Madrid's most successful publicity campaigns included the slogan "get on and see Madrid", which confirms this idea.

The Metro de Madrid brand is associated with modernity, innovation and efficient transport when compared to the EMT de Madrid brand.

Lastly, public transport is positively evaluated for its contribution to the sustainability of cities, both by users and the public in general. Moreover, users with a greater acquisitive power show more appreciation for the contribution that the service makes to sustainability, since they associate it with a healthy option for the city rather than a necessity in their transport criteria.

\subsection{Block 3: 'behaviour}

\subsubsection{Reasons for using public transport}

The response most frequently selected was to save money' followed by 'to save time', after which came 'no private transport'. A small percentage use it because of their 'social conscience', while out of the 'other responses', that which most stood out was the difficulty involved in getting to the city centre by car and the availability of parking metres. The creation of deterrent car parks in the main accesses of the big cities, to avoid the routes to the urban centre by car, is an important measure increasingly used by the transport public authorities in major Spanish cities. With these car parks, public car-transport intermodality is favoured, avoiding the entry of private vehicles into urban centres $[19,49]$. The reason for using public transport to save money was principally given by students and the unemployed. Those who are employed fundamentally use the service to save time. The principal reason given by retired people is the lack of a car or driving licence. Both the bus and the underground play a key role in work-related journeys. The use of public transport for leisure purposes is more widespread among younger users.

\subsubsection{Perception of the objectives of the service}

The order of priority obtained was exactly the same for both means of transport, and even the percentages were very similar, thus making the list more valid and reflecting a clear tendency. The figure below (Fig. 2) shows the response rates recorded on the Likert scale as "very important":

\subsubsection{Perception of the economic value of the service}

Users generally consider the service expensive. Nonetheless, the principal reason why users with less acquisitive power use this service is precisely to save money, although this might appear to be a contradiction.

The idea of obtaining a complementary income to finance the service through publicity is accepted by those surveyed. The greatest opposition to the idea of obtaining an additional income came from younger people, perhaps because they are a more demanding collective.

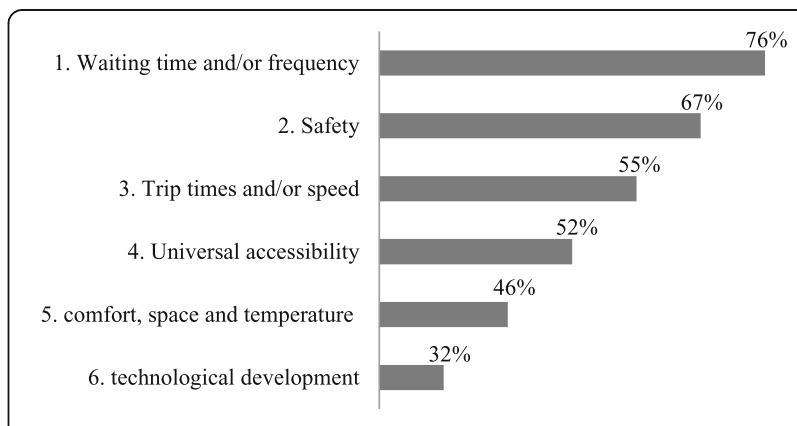

Fig. 2 Order of priority for using public transport. (Source: Authors) 
Pensioners or the unemployed whose subsidies may be threatened if the administrations increase the financing of transport are believe these companies should have greater financial autonomy.

Lastly, people associate the privatisation of the service with a decline in the welfare state and in the quality of the service; however, if it were possible to guarantee that this would not occur and that there efficient management would effectively reduce costs, then their opinion changes. Users consider that the public administration should be responsible for both the provision of the service and its financing.

\subsection{Results summary and contrast of hypothesis}

This was done by proposing a series of initial objectives that then served as a basis on which to contrast the hypothesis. The contrast has been carried out by selecting the survey questions that allow us to compare both means of transport, analysing questions from each block in the Servicescape (see Table 1). Contrast 1 is the arithmetic mean of the answers obtained in each question, and contrast 2 measures the dispersion in the answers to reinforce the affirmation made with contrast 1 . As indicated in the table below (Table 5), in the blocks "first impressions" and "feelings", the hypothesis is accepted in all cases. However, in the third block, "behaviour", the data show the bus is used with a slightly higher frequency, although it is considered more expensive than the underground service, so the results do not allow us to establish a conclusion about the preference between bus and underground. Based on the evidence gathered, the hypothesis can be accepted, and so the underground is more highly valued socially than the bus.

\section{Discussion}

This research has certain limitations that should be mentioned upon interpreting the results obtained. The first is that the study focuses solely on data obtained from Madrid. We therefore believe that it would be useful to carry out a study on the social perceptions of bus and underground users in the other Spanish cities in which these two means of transport coexist in order to obtain a more global view of the service in Spain. It would also be interesting to apply it to similar cities in neighbouring countries in order to verify whether the valuation and perception of the service are very different to those of Spanish users.

The second limitation is that the number of variables analysed in the questionnaire is considerable, thus making the questionnaire long, which may have led to exhaustion in those being surveyed. All the participants, therefore, were warned from the beginning that the average time needed to complete the questionnaire would be $8 \mathrm{~min}$.

\section{Conclusions}

This research work has enabled us to apply the advantages of the Servicescape Model and the methodology of the corresponding survey. The conclusions are divided into academic ones and industry ones to provide insights for academics, policy makers and transport practitioners.

\subsection{Academic conclusions}

This work has allowed us to understand local means of transport in the city of Madrid, not only from the perspective of the management of the industry but also from a user's perspective. Its originality and value for the scientific community lies in the lack of prior studies that have applied the Servicescape Model to public transport. The model has generally been applied to the study of tourist attractions, such as hotels, restaurants, museums and events. Our contribution, therefore, opens up new academic lines of inquiry and is a modest descriptive study of the general perception of the underground and local bus services, which could help the administrations in their current and future management.

\subsection{Conclusions for industry}

According to the survey carried out, the public considers it an expensive service. However, the income obtained is not sufficient to cover all expenses. It would appear that there is a gap between these companies' financial situation and the public's perception of the cost of the service, and this has led us to the conclusion that it is vital to provide information about the expenses that these companies incur, for example basic data such as income obtained from takings, income from subventions and the structure of expenses. This would thus make users aware of the value of the service received through the evolution of its prices, maintenance, security and employees' expenses, etc. Law 19/2013 on Transparency, Access to Public Information and Good Governance may enable the management efforts made by these companies to reach the public. It definitely appears necessary for the public to attain a higher level of confidence in this management.

According to the responses to the questionnaire, the general perception is that the collective profile of the public transport user is one of medium-low acquisitive power. We understand that this could be one of the reasons why certain members of the public of a particular 'status' refuse to use the service, as they do not wish to be associated with this more 'working class' profile. We believe that companies should design policies that will improve the image of the public transport service, which is linked to its user profile.

After analysing the perceptions of EMT de Madrid, we believe it will be necessary to carry out an analysis of the use of its website and aspects of it that could be 
Table 5 Summary of the contrast of the hypothesis in this research

\begin{tabular}{|c|c|c|c|c|c|}
\hline \multirow[t]{2}{*}{ Hypothesis } & \multicolumn{2}{|c|}{ Contrast 1} & \multicolumn{2}{|c|}{ Contrast $2\left(^{a}\right)$} & \multirow{4}{*}{ Result } \\
\hline & A & B & $\mathrm{C}$ & $\mathrm{D}$ & \\
\hline H: The Underground is more highly valued socially than the bus. & \multicolumn{2}{|c|}{ Arithmetic mean } & \multicolumn{2}{|c|}{$\begin{array}{l}\text { Typical dev. } \\
\text { (dispersion) }\end{array}$} & \\
\hline Block 1: First Impressions & Bus & $\begin{array}{l}\text { Under- } \\
\text { ground }\end{array}$ & Bus & $\begin{array}{l}\text { Under- } \\
\text { ground }\end{array}$ & \\
\hline \multicolumn{6}{|l|}{ Very Bad (1) to Very Good (5) } \\
\hline Quality of air and temperature & 2.920 & 3.090 & 1.120 & 1.092 & \multirow{7}{*}{$\begin{array}{l}\text { Given that } A<B \text {, the hypothesis can } \\
\text { be accepted. }\end{array}$} \\
\hline Space & 2.700 & 3.170 & 1.045 & 0.956 & \\
\hline Noise & 2.690 & 3.070 & 0.971 & 0.916 & \\
\hline Cleanliness, smell & 2.920 & 3.110 & 1.075 & 0.959 & \\
\hline Seats & 3.080 & 3.420 & 1.081 & 0.876 & \\
\hline Interior design and lighting & 3.290 & 3.680 & 0.877 & 0.761 & \\
\hline Average mean & 2.933 & 3.257 & 1.028 & 0.927 & \\
\hline \multicolumn{6}{|l|}{ Very Bad (5) to Very Good (1) } \\
\hline Sense of safety & 2.950 & 2.930 & 1.080 & 1.104 & \multirow{5}{*}{$\begin{array}{l}\text { Given that } A>B \text {, the hypothesis can } \\
\text { be accepted. }\end{array}$} \\
\hline Treatment received from employees & 2.730 & 2.750 & 1.027 & 0.962 & \\
\hline $\begin{array}{l}\text { The signposting at the end of the street that enables one to reach } \\
\text { the nearest stop }\end{array}$ & 2.450 & 2.260 & 0.945 & 1.001 & \\
\hline Average mean & 2.710 & 2.647 & 1.017 & 1.022 & \\
\hline Block 2: 'Feelings' & Bus & $\begin{array}{l}\text { Under- } \\
\text { ground }\end{array}$ & Bus & $\begin{array}{l}\text { Under- } \\
\text { ground }\end{array}$ & \\
\hline \multicolumn{6}{|l|}{ Greatly disagree (1) to Greatly agree (5) } \\
\hline $\begin{array}{l}\text { EMT de Madrid/Metro de Madrid associated with modernity, } \\
\text { innovation and efficient transport }\end{array}$ & 3.240 & 3.750 & 1.029 & 0.996 & \multirow[t]{2}{*}{$\begin{array}{c}\text { Given that } A<B \text {, the hypothesis car } \\
\text { be accepted. }\end{array}$} \\
\hline Average mean & 3.240 & 3.750 & 1.029 & 0.996 & \\
\hline \multicolumn{6}{|l|}{ Greatly disagree (5) to Greatly agree (1) } \\
\hline Transport by bus/underground makes the city more habitable. & 1.890 & 1.860 & 0.877 & 0.934 & \multirow{3}{*}{$\begin{array}{c}\text { Given that } A>B \text {, the hypothesis can } \\
\text { be accepted. }\end{array}$} \\
\hline Average mean & 1.890 & 1.860 & 0.877 & 0.934 & \\
\hline Block 3: Behaviour & Bus & $\begin{array}{l}\text { Under- } \\
\text { ground }\end{array}$ & Bus & $\begin{array}{l}\text { Under- } \\
\text { ground }\end{array}$ & \\
\hline \multicolumn{6}{|l|}{ Very often (1) to Very little (5) } \\
\hline Use the bus/underground for work purposes & 2.021 & 2.238 & 1.356 & 1.438 & \multirow{3}{*}{$\begin{array}{l}\text { Given that } A<B \text {, the hypothesis } \\
\text { cannot be accepted. }\end{array}$} \\
\hline Use the bus/underground for leisure purposes & 2.317 & 2.361 & 1.044 & 1.115 & \\
\hline Average mean & 2.169 & 2.299 & 1.200 & 1.277 & \\
\hline \multicolumn{6}{|l|}{ Very cheap (1) to Very expensive (5) } \\
\hline The current price of the bus/underground service is... & 1.875 & 1.757 & 0.706 & 0.695 & \multirow{2}{*}{$\begin{array}{c}\text { Given that } A<B \text {, the hypothesis can } \\
\text { be accepted. }\end{array}$} \\
\hline Average mean & 1.875 & 1.757 & 0.706 & 0.695 & \\
\hline
\end{tabular}

(Source: Authors)

(a) Contrast 2 shows strong similarities between bus and underground, so the dispersion does not modify the conclusion about contrast 1

improved, in addition to attempting to improve the perception of its image by creating a more modern and innovative profile, thus reflecting what it truly is. According to service users in Madrid, the main advantage of the underground, when compared to the bus service, is that it is faster and there are no traffic jams.

One measure that could, therefore, contribute to encouraging the use of buses in Madrid might be an increase in the number of HOV (High Occupancy Vehicle) lanes or BUS lanes, or the use of systems that would prevent these lanes from becoming blocked.

To sum up, the results obtained from the Servicescape analysis for both underground and bus reveal an acceptable management in terms of air quality, temperature, space, noise, cleanliness, smell and seats (average scores range from 2.4 to 3.7 out of 5). The 
underground has slightly better results than bus service. Improvements are suggested to draw the customer's attention: air conditioning equipment in strategic places, involvement of users in implementing adequate information and various participation schemes to improve the transport service, infrastructure maintenance such as seats, pavement and stations, green spaces for nature and biodiversity, installation of chill-out music speakers. Hence, better practices in the environment can improve the quality of public transportation and reduce traffic congestion. Small things can make a big impact.

\section{Acknowledgements}

This research work has taken place within the research project OPERET art. 83, code V634, financed by "Galileo Ingenieria y Servicios S.A."

\section{Authors' contributions}

MD carried out the literature review, contributing to the research giving the paper's academic structure and developing the conclusions obtained. AG carried out the questionnaire, collected the data and carried out the statistical analysis, incorporating the results from this research as a part of her doctoral thesis. JDE contributed to the statistical data treatment and the implementation of the Servicescape Model methodology into the questionnaire. All authors read and approved the final manuscript.

\section{Funding}

This manuscript is the result of the research work that were part of the above doctoral thesis, and that did not receive any funds for the preparation of it.

\section{Availability of data and materials}

The datasets generated and analysed during the current study are available in the doctoral thesis "Análisis del sector del transporte urbano colectivo en España: autobús versus metro, un enfoque multidisciplinar".

\section{Competing interests}

The authors declare that they have no competing interests.

Received: 5 March 2019 Accepted: 3 July 2019

Published online: 12 July 2019

\section{References}

1. Abenoza, R. F., Cats, O., \& Susilo, Y. O. (2017). Travel satisfaction with public transport: Determinants, user classes, regional disparities and their evolution. Transportation Research Part A: Policy and Practice, 95, 64-84. https://doi. org/10.1016/j.tra.2016.11.011.

2. Abreu e Silva, J., \& Bazrafshan, H. (2013). User satisfaction of intermodal transfer facilities in Lisbon, Portugal: Analysis with structural equations modeling. Transportation Research Record: Journal of the Transportation Research Board, 2350(1), 102-110. https://doi.org/10.3141/2350-12.

3. Aoki, S., \& Miyakawa, M. (2014). Statistical testing procedure for the interaction effects of several controllable factors in two-valued input-output system. Journal of Statistical Theory and Practice, 8(3), 546-557.

4. Axhausen, K. W., Haupt, T., Fell, B., \& Heidl, U. (2001). Searching for the rail bonus: Results from a panel SP/RP study. European Journal of Transport and Infrastructure Research, 1(4), 353-369.

5. Baker, J., Grewal, D., \& Parasuraman, A. (1994). The influence of store environment on quality inferences and store image. Journal of the Academy of Marketing Science, 22(4), 328-339. https://doi.org/10.1177/0092070394224002.

6. Baker, J., Levy, M., \& Grewal, D. (1992). An experimental approach to making retail store environmental decisions. Journal of Retailing, 68(4), 445.

7. Banister, D. (2011). The trilogy of distance, speed and time. Journal of Transport Geography, 19(4), 950-959. https://doi.org/10.1016/j. jtrangeo.2010.12.004.

8. Barnum, D. T., McNeil, S., \& Hart, J. (2007). Comparing the efficiency of public transportation subunits using data envelopment analysis. Journal of Public Transportation, 10(2), 1-16. https://doi.org/10.5038/2375-0901.10.2.1.
9. Bitner, M. J. (1986). Consumer responses to the physical environment in service settings. Creativity in services marketing, 43(3), 89-93.

10. Bitner, M. J. (1992). Servicescapes: The impact of physical surroundings on customers and employees. Journal of Marketing, 56(2), 57-71. https://doi. org/10.2307/1252042.

11. Bitner, M. J., Booms, B. H., \& Mohr, L. A. (1994). Critical service encounters: The employee's viewpoint. Journal of Marketing, 58(4), 95-106. https://doi. org/10.1177/002224299405800408.

12. Bitner, M. J., Booms, B. H., \& Tetreault, M. S. (1990). The service encounter: Diagnosing favorable and unfavorable incidents. Journal of Marketing, 54(1), 71-84. https://doi.org/10.2307/1252174.

13. Boniface, S., Scantlebury, R., Watkins, S. J., \& Mindell, J. S. (2015). Health implications of transport: Evidence of effects of transport on social interactions. Journal of Transport and Health, 2(3), 441-446. https://doi.org/10.1016/j.jth.2015.05.005.

14. Bowers, M. R., \& Martin, C. L. (2007). Trading places redux: Employees as customers, customers as employees. Journal of Services Marketing, 21(2), 8898. https://doi.org/10.1108/08876040710737859.

15. Brunner, A., Peters, M., \& Strobl, A. (2012). It is all about the emotional state: Managing tourists' experiences. International Journal of Hospitality Management, 31, 23-30. https://doi.org/10.1016/j.jhm.2011.03.004.

16. Bunschoten, T. (2012). To tram or not to tram: Exploring the existence of the tram bonus Graduation thesis, Delft University of Technology.

17. Carrasco, D., Toledano, D. S., \& Toledano, J. S. (2014). Observatorio de Costes y Financiación del Transporte Urbano Colectivo: Un programa de investigación. Investigaciones Europeas de Dirección y Economía de la Empresa, 20, 33-40

18. Cazzaro, M., \& Colombi, R. (2014). Marginal nested interactions for contingency tables. Communications in Statistics - Theory and Methods, 43(13), 2799-2814. https://doi.org/10.1080/03610926.2012.685550.

19. Chen, X., Liu, Z., \& Currie, G. (2016). Optimizing location and capacity of rail-based park-and-ride sites to increase public transport usage. Transportation Planning and Technology, 39(5), 507-526. https://doi.org/1 0.1080/03081060.2016.1174366.

20. Choo, H., \& Petrick, J. (2014). Social interactions and intentions to revisit for agritourism service encounters. Tourism Management, 40, 372-381. https:// doi.org/10.1016/j.tourman.2013.07.011.

21. Corner, A., \& Randall, A. (2011). Selling climate change? The limitations of social marketing as a strategy for climate change public engagement. Global Environmental Change, 21(3), 1005-1014. https://doi.org/10.1016/j. gloenvcha.2011.05.002

22. Creswell, J. W. (2012). Educational research: Planning, conducting, and evaluating quantitative and qualitative research (4th ed.). ISBN: 9780131367395. Pearson Education Inc.

23. Currie, G. (2010). Quantifying spatial gaps in public transport supply based on social needs. Journal of Transport Geography, 18(1), 31-41. https://doi. org/10.1016/j.jtrangeo.2008.12.002.

24. Delgado, M. L., Rivero, J. A., \& Sánchez, M. A. (2010). Movilidad y Financiación del Transporte en Tiempo de crisis. Análisis Local, 91, 31-40.

25. Dell'Olio, L., Ibeas, A., \& Cecín, P. (2010). Modelling user perception of bus transit quality. Transport Policy, 17(6), 388-397. https://doi.org/10.1016/j. tranpol.2010.04.006

26. Dell'Olio, L., Ibeas, A., \& Cecin, P. (2011). The quality of service desired by public transport users. Transport Policy, 18(1), 217-227. https://doi.org/10.1 016/j.tranpol.2010.08.005

27. Diab, E. I., \& El-Geneidy, A. M. (2012). Understanding the impacts of a combination of service improvement strategies on bus running time and passenger's perception. Transportation Research Part A, 46(3), 614-625. https://doi.org/10.1016/j.tra.2011.11.013.

28. Eboli, L., \& Mazzulla, G. (2011). A methodology for evaluating transit service quality based on subjective and objective measures from the passenger's point of view. Transport Policy, 18(1), 172-181. https://doi. org/10.1016/j.tranpol.2010.07.007.

29. García, G. (2005). La Investigación Comercial. Madrid: ESIC Chapters 4-6.

30. Gardner, M. P. (1985). Mood states and consumer behavior: A critical review. Journal of Consumer Research, 12(3), 281-300.

31. Gatersleben, B., Murtagh, N., \& White, E. (2013). Hoody, goody or buddy? How travel mode affects social perceptions in urban neighbourhoods. Transportation Research Part F: Traffic Psychology and Behaviour, 21, 219-230. https://doi.org/10.1016/j.trf.2013.09.005.

32. Gray, D. E. (2011). Doing research in the real world, second edition. Hampshire: Ashford Color Press. 
33. Hair, J., Black, W., Babin, B., \& Anderson, R. (2014). Multivariate data analysis (7th ed.). ISBN:978-0138132637. Pearson Education International.

34. Hair, J. J., Bush, R., \& Ortinau, D. (2006). Marketing Research (3rd ed.). Irwin: McGraw-Hill.

35. Heilig, G. K. (2012). World urbanization prospects: The 2011 revision (p. 14). New York: United Nations, Department of Economic and Social Affairs (DESA), population division, population estimates and projections section.

36. Hernández, S., Monzón, A., \& de Oña, R. (2016). Urban transport interchanges: A methodology for evaluating perceived quality. Transportation Research Part A: Policy and Practice, 84, 31-43. https://doi. org/10.1016/j.tra.2015.08.008

37. Holahan, C. (1982). Environmental psychology. New York: Random House, Inc

38. Iseki, H., \& Taylor, B. D. (2010). Style versus service? An analysis of user perceptions of transit stops and stations. Journal of Public Transportation, 13(3), 23-48.

39. Jarboui, S., Forget, P., \& Boujelbene, Y. (2012). Public road transport efficiency: A literature review via the classification scheme. Public Transport, 4(2), 101-128. https://doi.org/10.1007/s12469-012-0055-3.

40. Karlaftis, M. G. (2004). A DEA approach for evaluating the efficiency and effectiveness of urban transit systems. European Journal of Operational Research, 152(2), 354-364. https://doi.org/10.1016/S0377-2217(03)00029-8.

41. Karlaftis, M. G., \& Tsamboulas, D. (2012). Efficiency measurement in public transport: Are findings specification sensitive? Transportation Research Part A, 46, 392-402. https://doi.org/10.1016/j.tra.2011.10.005.

42. Kotler, P. (1973). Atmosphere as a marketing tool. Journal of Retailing, 49(4), 48-64.

43. Lai, W. T., \& Chen, C. F. (2011). Behavioral intentions of public transit passengers -the roles of service quality, perceived value, satisfaction and involvement. Transport Policy, 18(2), 318-325. https://doi.org/10.1016/j. tranpol.2010.09.003.

44. Li, Y. (2016). Infrastructure to Facilitate Usage of Electric Vehicles and its Impact. Transportation Research Procedia, 14, 2537-2543. https://doi.org/10.1 016/j.trpro.2016.05.337

45. Lin, Y., \& Worthley, R. (2012). Servicescape moderation on personality traits, emotions, satisfaction, and behaviors. International Journal of Hospitality Management, 31, 31-42. https://doi.org/10.1016/j.ijhm.2011.05.009.

46. Lipovetsky, S. (2014). Analytical closed-form solution for binary logit regression by categorical predictors. Journal of Applied Statistics, 42(1), $37-$ 49. https://doi.org/10.1080/02664763.2014.932760.

47. Lucas, K. (2012). Transport and social exclusion: Where are we now? Transport Policy, 20, 105-113. https://doi.org/10.1016/j.tranpol.2012.01.013.

48. Martín-Pliego, F. J., \& Ruiz-Maya, L. (2005). Fundamentos de inferencia estadística. Madrid: Paraninfo.

49. Monzón, A., Cascajo, R., Pieren, G., Romero, C., \& Delso, J. (2017). Informe del Observatorio de la Movilidad Metropolitana 2015. Ministerio de Agricultura y Pesca, Alimentación y Medio Ambiente.

50. Morton, C., Caulfield, B., \& Anable, J. (2016). Customer perceptions of quality of service in public transport: Evidence for bus transit in Scotland. Case Studies on Transport Policy, 4(3), 199-207. https://doi. org/10.1016/j.cstp.2016.03.002.

51. Neirotti, P., De Marco, A., Cagliano, A. C., Mangano, G., \& Scorrano, F. (2014). Current trends in Smart City initiatives: Some stylised facts. Cities, 38, 25-36. https://doi.org/10.1016/j.cities.2013.12.010.

52. Orth, U., Heinrich, F., \& Malkewitz, K. (2012). Servicescape interior design and consumers' personality impressions. Journal of Services Marketing, 26(3), 194 203. https://doi.org/10.1108/08876041211223997.

53. Pantouvakis, A. (2010). The relative importance of service features in explaining customer satisfaction: A comparison of measurement models. Managing Service Quality: An International Journal, 20(4), 366-387. https:// doi.org/10.1108/09604521011057496.

54. Petros, S., \& Enquist, B. (2016). Sustainable public transit service value network for building living cities in emerging economies: Multiple case studies from public transit services. Procedia - Social and Behavioral Sciences, 224(15), 263-268. https://doi.org/10.1016/j.sbspro.2016.05.458.

55. Redman, L., Friman, M., Gärling, T., \& Hartig, T. (2013). Quality attributes of public transport that attract car users: A research review. Transport Policy, 25, 119-127. https://doi.org/10.1016/j.tranpol.2012.11.005.

56. Reimer, A., \& Kuehn, R. (2005). The impact of servicescape on quality perception. European Journal of Marketing, 39(7/8), 785-808. https://doi. org/10.1108/03090560510601761.

57. Roukouni, A., Macharis, C., Basbas, S., Stephanis, B., \& Mintsis, G. (2018). Financing urban transportation infrastructure in a multi-actors environment:
The role of value capture. European Transport Research Review, 10(1), 1. https://doi.org/10.1007/s12544-017-0281-5.

58. Sampaio, B. R., Neto, O. L., \& Sampaio, Y. (2008). Efficiency analysis of public transport systems: Lessons for institutional planning. Transportation Research, Part A: Policy Practice, 42(3), 445-454. https://doi.org/10.1016/j.tra.2008.01.006.

59. Scherer, M. (2011). The image of bus and tram: First results. Ascona: 11th Swiss Transport Research conference.

60. Shostack, G. L. (1977). Breaking free from product marketing. Journal of Marketing, 41(2), 73-80. https://doi.org/10.2307/1250637.

61. Šimeček, M., Gabrhel, V., Tögel, M., \& Lazor, M. (2018). Travel behaviour of seniors in Eastern Europe: A comparative study of Brno and Bratislava. European Transport Research Review, 10(1), 1. https://doi.org/1 0.1007/s12544-018-0286-8.

62. Spies, K., Hesse, F., \& Loesch, K. (1997). Store atmosphere, mood and purchasing behavior. International Journal of Reasearch in Marketing, 14, 117. https://doi.org/10.1016/S0167-8116(96)00015-8.

63. Swartz, T., \& lacobucci, D. (1999). Handbook of services marketing and management ISBN: 978-0761916123. SAGE Publications, Inc.

64. Thomson, J. M. (1974). Teoría económica del transporteEditorial. Madrid: Alianza.

65. Tirachini, A., Hensher, D. A., \& Rose, J. M. (2013). Crowding in public transport systems: Effects on users, operation and implications for the estimation of demand. Transportation Research Part A: Policy and Practice, 53, 36-52. https://doi.org/10.1016/j.tra.2013.06.005.

66. Upah, G. D., \& Fulton, J. N. (1985). Situation creation in services marketing. The service encounter, 5(12), 255-264.

67. Utsunomiya, K. (2016). Social capital and local public transportation in Japan. Research in Transportation Economics, 59, 434-440. https://doi.org/1 0.1016/j.retrec.2016.02.001.

\section{Publisher's Note}

Springer Nature remains neutral with regard to jurisdictional claims in published maps and institutional affiliations.

\section{Submit your manuscript to a SpringerOpen ${ }^{\circ}$ journal and benefit from:}

- Convenient online submission

Rigorous peer review

- Open access: articles freely available online

- High visibility within the field

- Retaining the copyright to your article

Submit your next manuscript at $>$ springeropen.com 